\title{
Diversity and Host Range of Fruit Flies (Diptera: Tephritidae) in Horticultural Commodities in Lembah Seulawah District, Aceh Besar Regency, Aceh Province, Indonesia
}

\author{
Hendrival $^{* 1}$, Dewi Sartika Aryani' ${ }^{\text {, Nanda Saputri }}{ }^{1}$ \\ ${ }^{1}$ Department of Agroecotechnology, Faculty of Agriculture, Universitas Malikussaleh, Aceh Utara, Indonesia \\ Reuleut Campus, Muara Batu, Aceh Utara 24355, Indonesia \\ *Corresponding author: hendrival@unimal.ac.id
}

\section{ARTICLE HISTORY}

Received : 10 January 2020

Revised : 18 March 2020

Accepted : 14 April 2020

\section{KEYWORDS}

Fruit Flies

Species Diversity

Host Range

Species Dominance

Lynfield trap

\begin{abstract}
Accurate information on the species and host spectrum is an important aspect of fruit flies management. The study was conducted in August to November 2018 to evaluate the host range and species diversity of fruit flies in Lembah Seulawah District, Aceh Besar Regency, Aceh Province, Indonesia. Fruit flies were collected from 3 villages in Kemukiman Saree: Suka Damai, Suka Mulia, and Saree Aceh. The insects were collected using the trapping method. The modified Lynfield trap baited with methyl eugenol (ME) was used in the research. This modified Lynfield trap was applied using used mineral bottles. Shannon-Wiener diversity index, evenness index, and dominance were applied to determine the diversity of fruit flies. The results revealed that there were six species of fruit flies that acted as pests in 21 species of host plants belonged to 12 families. They were Bactrocera carambolae, Bactrocera latifrons, Bactrocera limbifera, Bactrocera papayae, Bactrocera umbrosa, and Bactrocera verbascifoliae. B. carambolae was found to be dominant insect pest even though the results indicated that diversity and evenness index of fruit flies species in this district were low.
\end{abstract}

\section{INTRODUCTION}

Indonesia, as it is located in a tropical region, is known as a producer of a variety of eminent and tasteful fruits. This superiority demonstrated by Indonesian fruits enabled them to compete with imported fruits, which is the demand of it is getting higher, resulting in higher development of the fruit plants. However, there are some obstacles faced by farmers in developing these local fruits, such as the supply of quality seeds, cultivation system, harvest handling, and also pest attack, especially fruit flies. Fruit flies are one of the important pests of horticultural plants in the tropics and subtropics (Hasyim, et al., 2016; Hafsi, et al., 2016). These pests belong to the order Diptera, family Tephritidae, and subfamily Dacinae. In the world, there are more than 4,000 species of Tephritidae consisting of 500 genera, 160 of which were found in Asia (Siwi, et al., 2006). Most fruit flies are polyphagous (Ortiz, et al., 2006). These Dipteran flies are known as the main pest of fruit plants and several kinds of vegetables (Nismah \& Susilo, 2008; Indriyanti, et al., 2014). Susanto, et al. (2017) also found that around $75 \%$ of fruit plants are attacked by fruit fly pests. The presence of fruit flies in fruit and vegetable crops is a major proble- $m$ in agribusiness that is often experienced by farmers.

Fruit fly attacks have caused both qualitative and quantitative damages (Larasati, et al., 2013). These flies are considered harmful because they directly attack agricultural products, such as fruit. The symptom of attacked fruit varies. Quantitative damage occurs due to a decrease in the number of fruit crops so that they cannot be harvested. Damage caused by fruit flies cannot be repaired due to the influence of the activity of bacterial decomposers. Besides, the activity of fruit fly larvae can also damage the flesh of the fruit so that the fruit will rot and fall before reaching maturity and it can reduce the competitiveness of horticultural commodities in the global market (Sarjan, et al., 2018). When the fly population is higher, the intensity of their attacks can reach 60-100\% (Pramudi, et al., 2014). Susanto, et al. (2017) reported that fruit flies attacking papaya plants could cause yield losses up to $100 \%$. An important factor influencing the presence and diversity of fruit flies in Indonesia is the presence of a host that acts as a food source. 
Some areas with different habitat types and landscape characters are known to have a high diversity of fruit fly hosts that can support species diversity and high fruit fly populations (Larasati, et al., 2013). Siwi, et al. (2006) have published information on the taxonomy and diversity of fruit fly species spread in Indonesia. However, studies on the ecological scope of fruit fly pests and their associations with host plants in Lembah Seulawah District are particularly limited. The purpose of this study was to evaluate the diversity and dominance of fruit fly species and to investigate the species of fruit fly host in Lembah Seulawah District, Aceh Besar Regency, Aceh Province, Indonesia.

\section{MATERIALS AND METHODS}

\subsection{Sample Collection}

The sampled fruits and vegetables were collected from 3 villages in Lembah Seulawah District, Aceh Besar Regency, Aceh Province, Indonesia such as Suka Damai, Suka Mulia, and Aceh Saree. The selection of samples was based on the presence and number and type of hosts that appeared in the area.

\subsection{Trap Devices}

The modified Lynfield lure trap was made by modifying used mineral bottles and was set to trap the insects, for comparison with the insects attracted to fruits and vegetables. These used mineral bottles were then perforated with a diameter of $5 \mathrm{~cm}$. Then the bottom of the bottle was perforated and used to hang the thread that is bound with cotton measuring $3 \mathrm{~cm}$. The hanging cotton was applied with methyl eugenol (ME). The Lynfield Trap is a disposable, made of clear plastic. The traps were hung in the sampled plants at about $1.5 \mathrm{~m}$ above ground, in an open place, avoiding predator attacks and other technical problems. The distance of the trap placed in the field ranges from $0.25-0.5 \mathrm{~km}$ per trap. With this trap, the male fruit flies were attracted to the trap and feed the lure insecticide mixture (ME). Flies then died and were retained dry in the trap. It would make the flies were easy to identify. The sample collection was carried out twice a week.

\subsection{Calculation of Fruit Flies Collected}

The calculations done for insects collected at each sampled plant. The trapped fruit flies were collected and placed into bottles of fruit fly specimens. The bottles were labeled with sample number, location, date of collection, and type of host. The specimens obtained were then taken to the Plant Pest and Disease Laboratory, Faculty of Agriculture, Universitas Malikussaleh to be identified.

\subsection{Identification of Fruit Flies}

The identification was carried out at Plant Pest and Disease Laboratory, Faculty of Agriculture, Universitas Malikussaleh. To be identified, the adult insects must be pinned using a micro pine $(15 \mathrm{~mm})$, which was inserted into the thorax of the insects. The insects were identified based on AQIS (2008) and Larasati, et al. (2016).

\subsection{Data Analysis}

Data collected were described descriptively using tables. Shannon-Wiener index $\left(\mathrm{H}^{\prime}\right)$ was applied for measuring species diversity, evenness (E), species richness (S), and species dominance (D). It is calculated in the following way $H^{\prime}=\Sigma P i \ln P i$, where $\mathrm{P}_{\mathrm{i}}=$ proportion of individuals found in species. For a well-sampled community, it is estimated that this proportion as $\mathrm{Pi}=\mathrm{n} / \mathrm{N}$, where $\mathrm{n}_{\mathrm{i}}$ is the number of individuals in species $\mathrm{i}$, and $\mathrm{N}$ is the total number of individuals in the community. The diversity is considered low if $0<\mathrm{H}^{\prime} \leq 1$, followed by moderate $\left(0<\mathrm{H}^{\prime} \leq 3\right)$ and high $\left(\mathrm{H}^{\prime}>3\right)$. For the evenness index, the formula is $\mathrm{E}=$ $\mathrm{H}^{\prime} / \mathrm{ln} \mathrm{S}$, where $\mathrm{E}$ is evenness index, and $\mathrm{S}$ is a number of species. The evenness is categorized as low if $0<\mathrm{E} \leq 0.4$, moderate if $0<\mathrm{E} \leq 0.6$ and high if $\mathrm{E}>0.6$. Relative frequency (F) is calculated using formula $F=n_{i} / N$, and species dominance is characterized by the percentage of fruit flies higher than $1 / \mathrm{S}(\mathrm{D}=1 /$ total number of species collected). The species can be categorized as dominance when the value of $F$ is higher than the value of $D(F>D)$.

\section{RESULTS AND DISCUSSIONS}

\subsection{Fruit Fly Species}

There were 6 species of fruit flies found in horticultural commodities in Lembah Seulawah District. They were Bactrocera carambolae, Bactrocera latifrons, Bactrocera limbifera, Bactrocera papayae, Bactrocera umbrosa and Bactrocera verbascifoliae (Table 1). Species B. carambolae, also known as important pest in star fruit plant, is the most abundant insect, spread from Java Island, Lombok, Eastern Sumbawa, and Kalimantan Island. This species is considered as a potential pest in Indonesia, where star fruit plant is common to be planted throughout Indonesia. From the observation in the field, Bactrocera dorsalis (Hendel), B. umbrosa (Fabricius), and B. carambolae Drew \& Hancock were the most insects caught by lure trap applied with ME. Sarjan, et al. (2018) found that the insects often attracted to ME because this product has the same compound produced by plants around the traps were located. Shelly, et al. (2014) also stated that ME could be obtained from the extraction of 450 plant species of 80 families. The compound can be extracted from flowers, leaves, roots, stems, or even the whole plant.

\subsection{Host Range}

In this research, 21 species of host plants from 12 families have been observed and B. carambolae has been caught attacking all plants (Table 1). This species is known as a polyphagous fruit-infesting fly that is able to attack most of the horticultural products, and it is more destructive compared to other fruit fly species. Besides, B. carambolae has a higher ability to adapt in the environment and spread widely in high numbers compared to other species. 
A wide range of host also influences the existence of this insect. This result corroborates with the research of Sahetapy, et al. (2019), who found that B. carambolae attacked star fruit and chili plants in a high population in Maluku, Indonesia. CABI (2019) examined that this species has several host plants such as star fruit, water apple, guava, tomato, chili, jackfruit, eggplant, orange, lemon, lime, mangosteen, bilimbi, cempedak, breadfruit, sapodilla, mango, sugar palm, soursup, country almond, etc. Marchioro (2016) reported that the insect had attacked $90 \%$ of cashew, followed by papaya (78\%), tangerine $(51 \%)$, guava (38\%), lemon $(30 \%)$, orange (29\%), mango (24\%) and avocado (20\%).

Table 1. The families and species of host plants associated with fruit flies in Lembah Seulawah District, Aceh Besar Regency, Province Aceh

\begin{tabular}{|c|c|c|c|c|c|c|c|c|}
\hline \multirow{2}{*}{ Families } & \multirow{2}{*}{ Hosts } & \multirow{2}{*}{ Common Name } & \multicolumn{6}{|c|}{ Fruit fly species } \\
\hline & & & 1 & 2 & 3 & 4 & 5 & 6 \\
\hline Anacardiaceae & Mangifera indica & Mango & $\sqrt{ }$ & & $\sqrt{ }$ & & $\sqrt{ }$ & \\
\hline \multirow[t]{2}{*}{ Annonaceae } & Annona muricata & Sirsak & $\sqrt{ }$ & & & $\sqrt{ }$ & & $\sqrt{ }$ \\
\hline & Annona squamosa & Srikaya & $\sqrt{ }$ & & & $\sqrt{ }$ & $\sqrt{ }$ & \\
\hline Cactaceae & Hylocereus undatus & Dragon fruit & $\sqrt{ }$ & & & $\sqrt{ }$ & $\sqrt{ }$ & \\
\hline Caricaceae & Carica papaya & Papaya & $\sqrt{ }$ & & & $\sqrt{ }$ & & \\
\hline \multirow[t]{2}{*}{ Cucurbitaceae } & Citrullus lanatus & Watermelon & $\sqrt{ }$ & & & & & \\
\hline & Cucumis sativus & Cucumber & $\sqrt{ }$ & $\sqrt{ }$ & & $\sqrt{ }$ & & \\
\hline Lauraceae & Persea americana & Avocado & $\sqrt{ }$ & $\sqrt{ }$ & & & & $\sqrt{ }$ \\
\hline Moraceae & Artocarpus heterophyllus & Jackfruit & $\sqrt{ }$ & & & $\sqrt{ }$ & $\sqrt{ }$ & \\
\hline \multirow[t]{2}{*}{ Myrtaceae } & Syzygium aqueum & Water apple & $\sqrt{ }$ & & & $\sqrt{ }$ & & \\
\hline & Psidium guajava & Guava & $\sqrt{ }$ & & & $\sqrt{ }$ & $\sqrt{ }$ & \\
\hline Oxalidaceae & Averrhoa carambola & Star fruit & $\sqrt{ }$ & & & & $\sqrt{ }$ & $\sqrt{ }$ \\
\hline \multirow[t]{4}{*}{ Rutaceae } & Citrus reticulate & Citrus & $\sqrt{ }$ & & & $\sqrt{ }$ & & \\
\hline & Citrus aurantifolia & Lime & $\sqrt{ }$ & & & $\sqrt{ }$ & $\sqrt{ }$ & \\
\hline & Citrus maxima & Pomelo & $\sqrt{ }$ & & & $\sqrt{ }$ & & \\
\hline & Citrus limon & Lemon & $\sqrt{ }$ & & & $\sqrt{ }$ & $\sqrt{ }$ & \\
\hline Sapotaceae & Manilkara zapota & Sapodilla & $\sqrt{ }$ & & & & $\sqrt{ }$ & \\
\hline \multirow[t]{4}{*}{ Solanaceae } & Capsicum annuum & Chili pepper & $\sqrt{ }$ & & & $\sqrt{ }$ & & \\
\hline & Capsicum frutescens & Tabasco pepper & $\sqrt{ }$ & $\sqrt{ }$ & & $\sqrt{ }$ & & \\
\hline & Solanum melongena & Eggplant & $\sqrt{ }$ & & $\sqrt{ }$ & & & \\
\hline & Solanum lycopersicum & Tomato & $\sqrt{ }$ & & & $\sqrt{ }$ & $\sqrt{ }$ & \\
\hline Total family & & & 12 & 3 & 2 & 8 & 8 & 3 \\
\hline Total species & & & 21 & 3 & 2 & 15 & 10 & 3 \\
\hline
\end{tabular}

Note: $1=$ B. carambolae, $2=$ B. latifrons, $3=$ B. limbifera, $4=$ B. papayae, $5=$ B. umbrosa, $6=$ B. verbascifoliae

The differences in fruit fly groups which distinguished by the range of hosts on fruit fly species, can occur due to the coevolution process that occurs between fruit fly species and their hosts. The difference in the range of hosts possessed by fruit fly species is influenced by the preferences and perceptions of fruit flies for the morphology, nutrition, distribution, and quantity of host plants and interactions with other organisms and individuals. For example, Tariyani, et al. (2013) found that in Maluku, B. papayae preferred to attack chili plants, $B$. cucurbitae preferred bitter melon (pare), and $B$. albistrigata has been caught the most in water apple and Malay apple (jambu bol). Hafsi, et al. (2016) also investigated that nutrition in host plants also contributed to flies' direction and selection of host plants. The direction of the insect for water concentration was opposite to the direction for the insect for carbohydrate, fiber, and lipid concentration.

\subsection{Fruit Fly Population}

During the observation, B. carambolae was a dominant species captured in the field (525 individuals), followed by $B$. papayae (58 individuals), B. verbascifoliae (26 individuals), B. umbrosa (18 individuals), B. latifrons (18 individuals) and the lowest was B. limbifera (4 individuals) (Table 2). The significant number of species found in the field could be attributed to several factors such as the conditions of habitat and the surroundings, also the suitability and availability of hosts in the field. According to Sunarno \& Popoko (2013), the availability and sufficiency of food affected the development of this 
tephritid fruit fly. The abundance of its population differs by the existence of host, the number of hosts, also its ability to adapt in the environment. Larger areas often attributed to a larger number of fruit fly populations due to the possibility of available host plants and suitable habitat.

Table 2. Population of fruit fly species in several host plants in Lembah Seulawah District, Aceh Besar Regency, Aceh Province

\begin{tabular}{|c|c|c|c|c|c|c|c|c|}
\hline \multirow{2}{*}{ Host families } & \multirow{2}{*}{ Host species } & \multirow{2}{*}{ Common name } & \multicolumn{6}{|c|}{ Fruit fly species } \\
\hline & & & 1 & 2 & 3 & 4 & 5 & 6 \\
\hline Anacardiaceae & Mangifera indica & Mango & 16 & & 1 & & 1 & \\
\hline \multirow[t]{2}{*}{ Annonaceae } & Annona muricata & Soursop & 14 & & & 5 & & 22 \\
\hline & Annona squamosa & Sugar apple & 132 & & & 5 & 3 & \\
\hline Cactaceae & Hylocereus undatus & Dragonfruit & 20 & & & 3 & 1 & \\
\hline Caricaceae & Carica papaya & Papaya & 6 & & & 3 & & \\
\hline \multirow[t]{2}{*}{ Cucurbitaceae } & Cucumis sativus & Cucumber & 31 & 14 & & 2 & & \\
\hline & Citrullus lanatus & Watermelon & 11 & & & & & \\
\hline Lauraceae & Persea americana & Avocado & 12 & 2 & & & & 1 \\
\hline Moraceae & Artocarpus heterophyllus & Jackfruit & 38 & & & 12 & 4 & \\
\hline \multirow[t]{2}{*}{ Myrtaceae } & Syzgium aqueum & Water apple & 34 & & & 1 & & \\
\hline & Psidium guajava & Guava & 19 & & & 4 & 1 & \\
\hline Oxalidaceae & Averrhoa carambola & Starfruit & 12 & & & & 1 & 3 \\
\hline \multirow[t]{4}{*}{ Rutaceae } & Citrus reticulate & Orange & 19 & & & 4 & & \\
\hline & Citrus aurantifolia & Lime & 14 & & & 1 & 1 & \\
\hline & Citrus maxima & Pomelo & 19 & & & 9 & & \\
\hline & Citrus limon & Lemon & 14 & & & 1 & 1 & \\
\hline Sapotaceae & Manilkara zapota & Sapodilla & 55 & & & & 3 & \\
\hline \multirow[t]{4}{*}{ Solanaceae } & Capsicum annuum & Chili pepper & 19 & & & 4 & & \\
\hline & Capsicum frutescens & Tabasco pepper & 11 & 2 & & 1 & & \\
\hline & Solanum melongena & Eggplant & 15 & & 3 & & & \\
\hline & Solanum lycopersicum & Tomato & 14 & & & 3 & 2 & \\
\hline Total & & & 525 & 18 & 4 & 58 & 18 & 26 \\
\hline
\end{tabular}

Note: $1=$ B. carambolae, $2=$ B. latifrons, $3=$ B. limbifera, $4=$ B. papayae, $5=$ B. umbrosa, $6=$ B. verbascifoliae

We investigated that B. carambolae was higher in number compared to other insects found in the area due to the wider range of host plants, so that this insect is able to develop on hundreds of plant species belonging to numerous families. Pasinato, et al. (2019) informed that $B$. carambola is a polyphagous insect which is cosmopolite and often can be found in higher number in an area. AQIS (2008) also agreed that B. carambolae has ability to disperse at high densities. Astriyani, et al. (2016) confirmed that the number of fruit fly population is not only influenced by host plants, but also by the existence of natural enemies. Natural enemies play an important role in managing fruit fly population in environment. Castilho, et al. (2019) assessment on B. carambolae found that the long oviposition period of this insect can expressively increase the damage in the field.

The results showed that B. papayae demonstrated moderate number in population eventhough this species has been captured in almost all sampled plants. This can be caused by its habitat, where this habitat influences the development of insect species. B. verbascifoliae, $B$. umbrosa, B. latifrons and B. limbifera were found in lower number in the location of research. It is assumed that the location was unsuitable for the development of these insect species.

\subsection{Diversity of Fruit Fly Species}

Sampled fruit fly adults caught by ME attractant could be used to examine the diversity of fruit fly species in Leumbah Seulawah District, Aceh Besar District. Based on the results from trap devices using ME, 6 species of fruit flies such as B. carambolae, B. latifrons, B.limbifera, B. papayae, B. umbrosa and $B$. verbascifoliae have been trapped. Among these six species, B. carambolae was dominant in number compared to five other species. The non-dominant species of fruit fly is a species that is rarely found and has a small population. This rare species can be a species that lives and feeds in a habitat or may only be an unidentified explorer. While the dominant species are species with a great abundance because this species has a large number of individuals, biomass, and importance so that it dominates the community. 
The results of the analysis of the diversity index of fruit flies in each location of the host sample showed a relatively low value (Table 3 ). The low diversity index value is caused by the low number of species of fruit flies and individuals per species found during observation at all host sampling locations; a community is said to have a high species diversity index value if the community arranged by many species with an abundance of species that are the same or nearly the same. Conversely, if a community is composed of many species, and if only a few species are dominant, then the diversity is low. The results of the analysis of the evenness index of the fruit flies at each location of the host sample showed a relatively low value (Table 3). The value of the Shannon Diversity Index $\left(\mathrm{H}^{\prime}\right)$ is influenced by the evenness of species in a community. The value of species evenness will tend to be low if the community is dominated by one species (Magurran, 2013).

Table 3. The number of insects, diversity index, species evenness, species dominance and dominance categories of fruit flies in Lembah Seulawah District, Aceh Besar Regency, Province Aceh

\begin{tabular}{|c|c|c|c|c|}
\hline Insect species & Number of insects $(\mathrm{N})$ & Relative Frequency (F) & D Value & $\mathrm{D}$ \\
\hline Bactrocera carambolae & 525 & 0.8089 & 0.1667 & Dominant \\
\hline Bactrocera latifrons & 18 & 0.0277 & 0.1667 & Non dominant \\
\hline Bactrocera limbifera & 4 & 0.0062 & 0.1667 & Non dominant \\
\hline Bactrocera papaya & 58 & 0.0894 & 0.1667 & Non dominant \\
\hline Bactrocera umbrosa & 18 & 0.0277 & 0.1667 & Non dominant \\
\hline Bactrocera verbascifoliae & 26 & 0.0401 & 0.1667 & Non dominant \\
\hline Total number of insects $(\mathrm{N})$ & 649 & & & \\
\hline Number of species (S) & 6 & & & \\
\hline Diversity Index (H') & -0.7464 & & & \\
\hline Species evenness (E) & -0.4166 & & & \\
\hline
\end{tabular}

B. carambolae was found to be dominant species in Lembah Seulawah District, Aceh Besar Regency (Table 3). The dominance of this species resulted from the wider range of host plants attacked by this fruit fly, which available in every season and spread widely in higher number. In addition, this insect has higher adaptability to the environment than other fruit fly species due to this insect is polyphagous. Pasinato, et al. (2019) also examined that $B$. carambolae can survive for a long period of time even though it was done in laboratory. According to Koswanudin, et al. (2018), the host plants of B. carambolae are star-fruits, bilimbi, pumpkin, water apple, guava, tomato, chili, jackfruit, cempedak, breadfruit, lemon, sapodilla, mangosteen, and mango. According to the research of Aketarawong, et al. (2015), the host plants of B. carambolae were varied in Southeast Asia, such as mountain soursop (Annona montana Macf.), soursop (Annona muricata L.), avocado (Persea americana Mill.), jackfruit (Artocarpus heterophyllus L.), bilimbi (Averrhoa bilimbi L.), pomegranate (Punica granatum L.), chili

\section{REFERENCES}

Aketarawong, N., Isasawin, S., Sojikul, P., \& Thanaphum, S. (2015). Gene flow and genetic structure of Bactrocera carambolae (Diptera, Tephritidae) among geographical differences and sister species, B. dorsalis, inferred from microsatellite DNA data. ZooKeys, 540, 239-272. doi:10.3897/zookeys.540.10058

Astriyani, N. K. N. K., Supartha, I. W., \& Sudiarta, I. P. (2016). Kelimpahan populasi dan persentase serangan lalat buah yang menyerang tanaman buah-buahan di Bali. Journal of Agricultural Science and Biotechnology, 5(1), 19-27.

[AQIS] Australian Quarantine and Inspection Service. (2008). Fruit
(Capsicum annuum L.) and tomato (Lycopersicon esculentum Mill.).

\section{CONCLUSIONS}

There were six species of fruit flies found in 23 species of fruit and vegetable plants belonged to 16 families in Lembah Seulawah District, Aceh Besar Regency. They were Bactrocera carambolae, Bactrocera latifrons, Bactrocera limbifera, Bactrocera papayae, Bactrocera umbrosa, and Bactrocera verbascifoliae.

B. carambolae was evaluated to be higher in number of population compared to other species. The diversity and evenness of other fruit fly species in the Lembah Seulawah were relatively low resulted from the dominance of B. carambolae.

Further research needs to be conducted on the diversity and population of fruit flies in Lembah Seulawah District, Aceh Besar Regency, which is carried out over a longer time span and in a wider variety of host plants.

Flies of Indonesia: Their Identification, Pest Status and Pest Management. Conducted by International Center for the Management of Pest Fruit Flies, Griffith University, Brisbane, Australia and Ministry of Agriculture, Republic of Indonesia.

[CABI] Center in Agricultural and Biological Institute. (2019). Invasive Species Compendium: Bactrocera carambolae (carambola fruit fly). Accessed from https://www.cabi.org/isc/datasheet/8700 (20 January 2019).

Castilho, A. P., Pasinato, J., Santos, J. E. V. dos, Costa, A. e S. da, Nava, D. E., Jesus, C. R. de, \& Adaime, R. (2019). Biology of Bactrocera carambolae (Diptera: Tephritidae) on four hosts. Revista Brasileira de Entomologia, 63(4), 302-307. doi:10.1016/j.rbe.2019.09.002 
Hafsi, A., Facon, B., Ravigné, V., Chiroleu, F., Quilici, S., Chermiti, B., \& Duyck, P.-F. (2016). Host plant range of a fruit fly community (Diptera: Tephritidae): does fruit composition influence larval performance? BMC Ecology, 16(1). doi:10.1186/s12898-0160094-8

Hasyim, A., Muryati, M., \& Kogel, W. J. D. (2016). Population fluctuation of adult males of the fruit fly, Bactrocera tau Walker (Diptera: Tephritidae) in passion fruit orchards in relation to abiotic factors and sanitation. Indonesian Journal of Agricultural Science, 9(1), 29-33. doi:10.21082/ijas.v9n1.2008.29-33

Indriyanti, D. R., Isnaini, Y. N., \& Priyono, B. (2014). Identifikasi dan kelimpahan lalat buah Bactrocera pada berbagai buah terserang. Biosaintifika: Journal of Biology \& Biology Education, 6(1), 39-45.

Koswanudin, D., Basukriadi, A., Samudra, I. M., \& Ubaidillah, R. (2018). Host preference fruit flies Bactrocera carambolae (Drew \& Hancock) and Bactrocera dorsalis (Drew and Hancock) (Diptera: Tephritidae). Jurnal Entomologi Indonesia, 15(1), 40-49. doi:10.5994/jei.15.1.40

Larasati, A., Hidayat, P., \& Buchori, D. (2013). Keanekaragaman dan persebaran lalat buah Tribe Dacini (Diptera: Tephritidae) di Kabupaten Bogor dan sekitarnya. Jurnal Entomologi Indonesia, 10(2), 51-59. doi:10.5994/jei.10.2.51

Marchioro, C. A. (2016). Global Potential Distribution of Bactrocera carambolae and the Risks for Fruit Production in Brazil. PLOS ONE, 11(11), e0166142. doi:10.1371/journal.pone.0166142

Magurran, A. E. (2013). Measuring biological diversity. John Wiley \& Sons.

Nismah \& Susilo, F. X. (2008). Keanekaragaman dan kelimpahan lalat buah (Diptera: Tephritidae) pada beberapa sistem penggunaan lahan di Bukit Rigis, Sumberjaya, Lampung Barat. J. HPT Tropika 8(2): 82-89.

Ortiz, H., Frias, D., \& Selivon, D. (2006). Taxonomy of Immature Stages: New Morphological Character for Tephritidae Larvae Identification. 7th International Symposium on Fruit Flies Economic Importance 10-15 September 2006. Brasil. 29-44 (Proceedings).

Pasinato, J., Redaelli, L. R., Botton, M., \& Jesus-Barros, C. R. de. (2019). Biology and fertility life table of Bactrocera carambolae on grape and acerola. Revista Brasileira de Entomologia, 63(3), 217-223. doi:10.1016/j.rbe.2019.06.001

Pramudi, M. I., Puspitarini, R. D., \& Rahardjo, B. T. (2014). Keanekaragaman dan kekerabatan lalat buah (Diptera: Tephritidae) di Kalimantan Selatan berdasarkan karakter morfologi dan molekular (RAPD-PCR dan sekuensing DNA). Jurnal Hama dan Penyakit Tumbuhan Tropika, 13(2), 192-202.

Sahetapy, B., Uluputty, M. R., \& Naibu, L. (2019). Identifikasi Lalat Buah (Bactrocera spp), pada Tanaman Cabai (Capsicum Annum L.) dan Belimbing (Averrhoa Carambola L.) di Kecamatan Salahutu Kabupaten Maluku Tengah. Jurnal Agrikultura, 30(2), 63-74. doi:10.24198/agrikultura.v30i2.23659

Sarjan, M., Yulistiono, H., \& Haryanto, H. (2018). Kelimpahan dan komposisi spesies lalat buah pada lahan kering di Kabupaten Lombok barat. CROP AGRO, Jurnal Ilmiah Budidaya, 3(2), 103-112.

Shelly, T., Epsky, N., Jang, E. B., Reyes-Flores, J., \& Vargas, R. (Eds.). (2014). Trapping and the Detection, Control, and Regulation of Tephritid Fruit Flies. Springer Dordrecht Heidelberg. New York doi:10.1007/978-94-017-9193-9

Siwi, S. S., \& Hidayat, P. (2006). Taksonomi dan bioekologi lalat buat penting di Indonesia (Diptera: Tephritidae). Kerjasama Balai Besar Penelitian dan Pengembangan Bioteknologi dan Sumberdaya Genetik Pertanian dengan Departement of Agriculture, Fisheries and Forestry Australia.

Sunarno, S. P. (2013). Keragaman jenis lalat buah (Bactrocera spp.) di Tobelo Kabupaten Halmahera Utara. Jurnal Agroforestri, 7(4),
269-275.

Susanto, A., Fathoni, F., Atami, N. N., \& Tohidin, T. (2017). Fluktuasi Populasi Lalat Buah (Bactrocera dorsalis Kompleks.) (Diptera: Tephritidae) pada Pertanaman Pepaya di Desa Margaluyu, Kabupaten Garut. Jurnal Agrikultura, 28(1), 32-38.

Tariyani, T., Patty, J. A., \& Siahaya, V. G. (2018). Identifikasi Lalat Buah (Bactrocera spp) di chili, bitter melon, jambu dan jambu bol di Kota Ambon. Agrologia, 2(1), 73-85. doi:10.30598/a.v2i1.281 